\title{
VARIABEL DALAM \\ PENELITIAN PENDIDIKAN
}

Oleh : Purwanto *

\section{Abstrak}

Pengumpulan data dalam penelitian pendidikan harus mempertimbangkan dua hal : 1) Dari siapa data di peroleh. Pertanyaan ini berhubungan dengan objek yang mempunyai sifat yang akan diukur yang dikenal sebagai reponden. 2) Karakteristik apa yang akan diukur. Responden mempunyai kesamaan dalam satu karakteristik sehingga menjadi satu populasi. Untuk memperoleh penyederhanaan dalam pengumpulan data mungkin pengumpulan tidak dilakukan atas populasi tetapi atas sampel. Di samping responden mempunyai kesamaan dalam satu karakteristik, antara responden mempunyai perbedaan dalam karakteristik yang lain yang disebut variabel. Data variabel dikumpulkan dengan mengukur kepemilikan variabel pada responden.

Kata kunci : responden, populasi / sampel, variabel

\section{A. PENDAHULUAN}

Penelitian kuantitatif yang digunakan dalam ilmu sosial dan pendidikan merupakan model penelitian yang meniru cara kerja penelitian alam. Salah satu cara kerja dalam penelitian alam yang dilakukan dalam penelitian sosial dan pendidikan adalah cara yang dilakukan dalam pengumpulan data. Dalam penelitian alam pengumpulan data dilakukan dengan cara melakukan pengukuran. Misalnya : pengumpulan data suhu pasien, berat suatu benda, jarak suatu tempat, waktu suatu proses dan sebagainya dilakukan dengan cara melakukan pengukuran. Pengukuran dilakukan sesuai dengan

*) Purwanto, M.Pd., adalah dosen STAIN Surakarta 
alat ukur dan keadaan yang diukur dapat berupa menimbang, mengukur, menakar, membandingkan dan sebagainya.

Pengukuran merupakan cara pengumpulan data yang dilakukan dengan membandingkan sesuatu yang diukur dengan alat ukurnya. Tinggi badan diukur dengan membandingkan benda dengan alat ukur mistar, berat badan diukur dengan membandingkan benda yang data beratnya akan dikumpulkan dengan alat ukur timbangan, suhu pasien diukur dengan membandingkan pasien dengan alat ukur termometer, dan sebagainya. Dalam membandingkan sesuatu yang diukur dengan alat ukurnya itu, data mengenai objek-objek yang diukur diberikan dengan menerakan angka pada objek sesuai kadar kepemilikan sifatnya dalam alat ukur yang digunakan.

Cara kerja pengumpulan data yang dilakukan dengan melakukan pengukuran juga menjadi tradisi pengumpulan data dalam penelitian sosial dan pendidikan yang dilakukan menggunakan metode kuantitatif. Dalam penelitian ini data dikumpulkan dari objek penelitian pada sifat tertentu yang dikenal dengan variabel. Pengukuran variabel dari objek penelitian memungkinkan skor angka dapat diterakan pada objek sesuai kadar kepemilikan variabel oleh objek sebagaimana ditunjukkan oleh alat ukurnya. Untuk memperjelas pembahasan mengenai variabel dan pengumpulan data, maka tulisan ini menyajikan pembahasan tentang variabel dan pengumpulan data.

\section{B. VARIABEL}

Untuk memahami pengumpulan data yang dilakukan dengan cara melakukan pengukuran, maka perlu dijelaskan sebelumnya sumber pengumpulan data, objek penelitian dan variabel. Objek penelitian alam adalah benda-benda yang darinya akan dikumpulkan datanya. Keseluruhan objek yang mempunyai satu karakteristik yang sama dinamakan populasi. Sumber pengumpulan data dapat berupa populasi atau sampel. Pengukuran dapat dilakukan pada semua benda yang menjadi bagian dari populasi, dapat pula dilakukan atas 
sebagian dari populasi yang dikenal sebagai sampel. Setelah jelas sumber pengumpulan data dan objeknya, maka dapat diukur sifat yang hendak diukur yang dikenal sebagai variabel. Untuk itu berikut dibahas tentang sumber pengumpulan data, objek penelitian dan variabel dalam penelitian. Hal itu dapat digambarkan sebagai berikut:

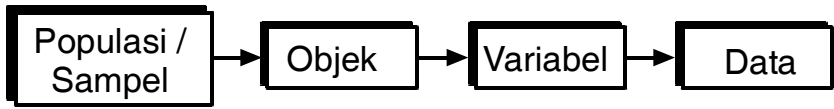

\section{Sumber pengumpulan data}

Pengukuran dapat dilakukan pada semua benda yang menjadi bagian dari populasi, dapat pula dilakukan atas sebagian dari populasi yang dikenal sebagai sampel. Populasi adalah keseluruhan unsur yang mempunyai satu karakteristik yang sama. Populasi logam adalah keseluruhan unsur yang mempunyai sifat yang sama yaitu logam. Apabila pengukuran dilakukan atas semua logam yang ada, maka sumber pengumpulan data adalah populasi, sedang bila sebagian logam yang menjadi sampel saja yang diukur untuk dikumpulkan datanya, maka sumber pengumpulan data adalah sampel.

\section{Objek penelitian}

Objek penelitian alam adalah benda-benda yang darinya akan dikumpulkan datanya. Pengumpulan data dilakukan atas objek yang sifatnya akan diukur untuk dikumpulkan datanya. Penelitian alam menempatkan benda alam - baik mati maupun hidup sebagai objek yang darinya data akan dikumpulkan. Penelitian mengenai pengaruh lama pemuaian dengan bertambah panjangnya logam menggunakan objek berupa logam. Dalam penelitian ini objek yang dikaji adalah logam. Sejumlah logam satu persatu dipanaskan dalam waktu tertentu dan diukur pertambahan panjangnya. Kesimpulan mengenai hubungan antara lama pemuaian dan pertambahan panjang logam pada beberapa logam itu kemudian menjadi sebuah temuan penelitian. 


\section{Variabel}

Alam terdiri dari sangat banyak ragam gejala yang acak, rumit, kompleks dan tidak beraturan. Keadaan demikian membuat alam menjadi sulit untuk dipahami oleh manusia. Penelitian membantu manusia menaklukan kerumitan alam sehingga ketidaktahuan manusia atas alam berubah menjadi pengetahuan. Usaha menaklukan kerumitan itu dilakukan dengan menyederhanakan kerumitan alam dengan memilih gejala tertentu dalam ukuran yang memungkinkan dapat dikelola karena bisa diobservasi dan terukur. Gejala tertentu yang disederhanakan dari kerumitan alam yang dipilih dalam ukuran yang dapat dikelola dikenal dengan istilah variabel.

Variabel adalah gejala yang dipersoalkan. Gejala bersifat membedakan satu unsur populasi dengan unsur yang lain. Oleh karena variabel bersifat membedakan maka variabel harus mempunyai nilai yang bervariasi. Populasi adalah keseluruhan objek yang mempunyai satu karakteritik yang sama. Meski seluruh objek anggota populasi mempunyai satu karakteristik yang sama sehingga menempatkan mereka ke dalam satu populasi, namun antara objek-objek yang menjadi anggota populasi berbeda dalam gejala yang lain. Gejala yang membedakan objek-objek yang menjadi anggota populasi dinamakan sebagai variabel. Misalnya : populasi terdiri dari 10 buah gedung. Populasi terdiri dari objek sebanyak 10 buah gedung sebagai anggota dan mereka menjadi populasi karena mempunyai satu karakteristik yang sama yaitu gedung. Meskipun 10 buah gedung mempunyai satu kesamaan, mereka mungkin berbeda dalam warna, tinggi, bahan, kualitas, usia, jumlah ruang, dan sebagainya. Gejala-gejala yang membedakan itu merupakan variabel. 


\section{VARIABEL DALAM PENELITIAN PENDIDIKAN}

Variabel mempunyai tiga ciri yaitu dapat diukur, membedakan objek dari objek lain dalam satu populasi dan nilainya bervariasi. 1) Variabel harus dapat diukur. Penelitian kuantitatif mengharuskan hasil penelitian yang objektif, terukur dan selalu terbuka untuk diuji. Variabel berbeda dengan konsep. Konsep belum dapat diukur, sedang variabel dapat diukur. Variabel adalah operasionalisasi konsep (Bouma, 1993 : 38). Misalnya : penampilan akademik adalah konsep dan hasil belajar adalah variabel, belajar adalah konsep dan strategi belajar adalah variabel, keadaan adalah konsep dan suhu adalah variabel dan sebagainya. Oleh karena itu, data variabel penelitian harus tampak dalam perilaku yang dapat diobservasi dan diukur. Misalnya : prestasi belajar adalah jumlah jawaban benar yang dibuat siswa dalam mengerjakan sebuah tes. 2) Variabel membedakan satu objek dari yang lainnya. Objek-objek menjadi anggota populasi karena mempunyai satu karakteristik yang sama. Meski sama, objek-objek dalam populasi dapat dibedakan satu sama lain dalam variabel. Misalnya : populasi siswa terdiri dari anggota yang memiliki satu kesamaan karakteriktik yaitu siswa. Disamping kesamaan itu, antara mereka berbeda dalam usia, jenis kelamin, agama, ras, tempat tinggal, prestasi belajar, pekerjaan orang tua, kecerdasan, bakat khusus, dan sebagainya. Perbedaan-perbedaan itu merupakan variabel karena mempunyai sifat membedakan. 3) Variabel mempunyai nilai yang bervariasi. Oleh karena variabel membedakan satu objek dengan objek lain dalam satu populasi, maka variabel harus mempunyai nilai yang bervariasi. Misalnya : dari populasi yang terdiri dari 50 orang siswa, jenis kelamin hanya akan menjadi variabel apabila dari 50 orang siswa bervariasi dalam jenis kelamin. Sebaliknya bila dari 50 orang siswa itu semuanya laki-laki, maka jenis kelamin bukan variabel.

Variabel dapat diklasifikasikan menggunakan beberapa cara penggolongan, yaitu berdasarkan sifat, kedudukan, skala, kemungkinan manipulasi, alat ukur pengumpulan data dan penampilan yang diukur. Menurut sifatnya, variabel dapat dibagi menjadi tiga yaitu variabel kategori, diskrit dan kontinum. 1) Variabel kategori adalah 
variabel yang dapat diklasifikasi secara pilah (mutually exclusive). Termasuk dalam variabel ini adalah jenis kelamin (laki-laki, perempuan), status perkawinan (belum, menikah, janda/duda), warna kulit (putih, hitam, sawo matang), suku (Jawa, Sunda, Batak, Bali, lainnya), dan sebagainya. 2) Variabel diskrit adalah variabel yang dikumpulkan datanya dengan cara membilang. Sebagai hasil proses membilang maka data diskrit mempunyai ukuran satuan yang utuh sehingga tidak memungkinkan data berupa pecahan. Termasuk dalam variabel ini adalah jumlah anak, jumlah penduduk, jumlah panen, usia, jumlah murid, jumlah sekolah, jumlah propinsi dan sebagainya. 3) Variabel kontinum adalah variabel yang datanya terdapat dalam suatu kontinum karena merupakan hasil dari proses mengukur. Hasil pengukuran berat sebesar $10 \mathrm{~kg}$ berada dalam suatu kontinum mungkin $9,98 \mathrm{~kg}$ atau $10,15 \mathrm{~kg}$. Data hasil pengukuran memungkinkan berbentuk pecahan karena hasil pengukuran berada dalam sebuah kontinum. Variabel dalam pendidikan yang tergolong kelompok variabel ini adalah motivasi belajar, minat membaca, prestasi belajar, konsep diri dan sebagainya.

Menurut kedudukannya, variabel dapat dibagi menjadi dua yaitu variabel bebas dan variabel terikat. Variabel bebas adalah variabel yang nilainya mempengaruhi variabel terikat. Sebaliknya variabel terikat adalah variabel yang nilainya dipengaruhi oleh variabel bebas. Dalam sebuah penelitian tentang hubungan antara lama pemuaian dengan bertambah panjangnya muai, maka lama pemuaian merupakan variabel bebas dan lama pemuaian merupakan variabel terikat. Namun dalam penelitian lain tentang hubungan antara pertambahan panjang muai dengan pertambahan berat maka pertambahan panjang muai tidak lagi merupakan variabel terikat tetapi variabel bebas untuk variabel terikat pertambahan berat. Hal itu disebabkan karena pada kedua penelitian variabel pertambahan panjang muai menempati kedudukan yang berbeda.

Beberapa variabel bebas kadang-kadang diabaikan. Variabel yang dapat menjadi variabel bebas tetapi diabaikan dikenal beberapa macam yaitu variabel moderator, kontrol, acak dan laten (intervening). 
1) Variabel moderator adalah variabel yang sebenarnya menjadi perantara variabel bebas tertentu dengan variabel terikatnya. Misalnya : metode mengajar berhubungan dengan hasil belajar dengan tingkat yang berbeda pada guru yang mempunyai jenis kelamin. Sehubungan dengan metode mengajar, jenis kelamin guru mempengaruhi hasil belajar, tetapi diabaikan dengan tidak memasukkannya ke dalam analisis. 2) Variabel kontrol adalah variabel yang menjadi variabel bebas dan dimasukkan ke dalam penelitian tetapi dibuat konstan dengan mengontrolnya. Misalnya : metode mengajar dan usia berhubungan dengan hasil belajar (metode mengajar tertentu hanya mempengaruhi hasil belajar pada tingkat usia tertentu). Usia dimasukkan ke dalam analisis, tetapi diabaikan dengan membuatnya menjadi konstan. 3) Variabel rambang atau acak adalah variabel yang pengaruhnya tidak terlalu menentukan sehingga dapat diabaikan pada sampel yang diambil secara acak. 4) Variabel laten (intervening) adalah variabel bebas yang dapat dikaji secara teoretik tetapi tidak dapat diobservasi. Misalnya : di antara hubungan antara kehadiran guru dengan prestasi belajar, terdapat variabel intervening berupa keaktifan belajar siswa.

Penggolongan lain mengelompokkan variabel menurut skalanya. Berdasarkan skalanya, variabel dapat dibedakan menjadi empat yaitu variabel nominal, ordinal, interval dan rasio. 1) Variabel nominal adalah variabel yang tingkat skalanya hanya memilah. Perbedaan nilai variabel tidak mempunyai makna apapun kecuali hanya untuk keperluan memberikan tanda atau label. Perbedaan nilai tidak mempunyai sifat untuk dapat diurutkan dengan aturan tertentu karena sifat skalanya yang nominal. Misalnya, bila variabel jenis kelamin dinilai dengan memberikan responden laki-laki dengan skor 1 (satu) dan perempuan dengan skor 0 (nol) tidak berarti bahwa laki-laki lebih tinggi daripada perempuan karena skornya lebih besar. Perbedaan skor semata hanya dilakukan untuk pemberian tanda. Termasuk ke dalam variabel nominal adalah agama, jenis kelamin, suku, pekerjaan, pendidikan, dan sebagainya. 2) Variabel ordinal adalah variabel yang peneraan skornya dimaksudkan untuk mengurutkan bahwa suatu objek lebih dari yang lain dalam variabel yang diukur. Oleh karenanya 
sebuah objek yang mempunyai skor lebih tinggi dari yang lain dapat dikatakan lebih dari objek lain dalam variabel yang diukur karena skala datanya ordinal. Dengan begitu dapat dikatakan bahwa siswa yang memperoleh nilai 95 dalam tes prestasi belajar lebih pandai daripada siswa yang memperoleh nilai 80 . Termasuk dalam variabel yang mempunyai skala ordinal adalah kecerdasan, prestasi belajar, kreativitas, minat menjadi guru, penguasaan bahasa asing, kemampuan penyesuaian diri dan sebagainya. 3) Variabel interval adalah variabel yang mempunyai skala dengan interval yang sama. Oleh karena mempunyai interval yang sama maka data-data dengan skala interval dapat dijumlahkan. Misalnya : tiga orang memperoleh skor motivasi belajar masing-masing 20, 30 dan 40. Meskipun selisih skor antara ketiganya sama yaitu 10, namun tidak berarti selisih kadar motivasi belajar ketiganya sama. Hal itu disebabkan karena data motivasi belajar hanya dapat diurutkan, tetapi tidak dapat dijumlahkan. Berbeda dengan data variabel suhu misalnya. Sebuah benda dengan suhu $60^{\circ} \mathrm{C}$ bila ditambahkan $40^{\circ} \mathrm{C}$ maka akan menjadi benda dengan suhu $100^{\circ} \mathrm{C}$. Hal itu dapat dilakukan karena suhu merupakan variabel dengan skala interval. 4) Variabel rasio adalah variabel yang mempunyai skala tingkat tertinggi. Skor datanya tidak hanya dapat dijumlahkan tetapi juga mempunyai 0 (nol) absolut. Suhu $0^{\circ} \mathrm{C}$ tidak dapat dikatakan sebagai suatu keadaan tanpa suhu, sebab angka 0 (nol) ditentukan secara sembarang, yaitu titik beku yang dalam skala celsius ditetapkan sebagai keadaan nol. Pada kenayataannya, titik beku dalam skala termometer Farenheit mempunyai suhu $32^{\circ} \mathrm{F}$. Berbeda dengan suhu, berat merupakan variabel yang mempunyai skala rasio. Berat $0 \mathrm{~kg}$ berarti keadaan tidak ada berat sama sekali. Berat $0 \mathrm{~kg}$ sama beratnya dengan 0 ton, 0 ons, 0 pounds dan sebagainya karena variabel berat merupakan variabel dengan skala rasio. Termasuk dalam variabel rasio adalah berat, jarak, waktu, dan sebagainya.

Menurut kemungkinannya dilakukan manipulasi, variabel dapat dibagi menjadi dua yaitu variabel aktif (perlakuan) dan variabel organismik (atribut). Variabel aktif adalah variabel yang dapat dimanipulasikan, seperti jenis pupuk, jenis obat yang diberikan, sistem imbalan, metode 
mengajar, konsekuensi perilaku, bentuk tes, jenis tes, dan sebagainya. Variabel atribut adalah variabel yang tidak dapat dimanipulasikan, seperti kecerdasan, motivasi, gaya kognitif, sikap dan sebagainya.

Menurut alat ukur pengumpulan datanya, variabel dapat digolongkan menjadi dua yaitu variabel faktual dan variabel konsep. 1) Variabel faktual adalah variabel yang alat ukurnya tidak perlu dibakukan karena kesalahan data bukan merupakan kesalahan alat ukurnya. Misalnya : bila responden tidak jujur mengisi data tentang variabel usia maka kesalahan tidak terletak pada alat ukurnya. Termasuk dalam variabel faktual adalah agama, jenis kelamin, usia, pendidikan, pekerjaan, asal daerah, asal sekolah dan sebagainya. 2) Sebaliknya, variabel konsep atau konstruk adalah variabel yang alat ukur pengumpulan datanya harus terlebih dulu dibakukan sebelum digunakan untuk pengumpulan data. Hal itu disebabkan karena ada kemungkinan kesalahan data disebabkan oleh instrumen alat ukur yang salah konsep. Misalnya : data motivasi belajar dapat menjadi salah karena butir-butirnya pertanyaannya tidak mengukur apa yang semestinya diukur (tidak valid) atau alat ukur motivasi belajar tidak memberikan hasil konsisten (tidak reliabel). Termasuk variabel konsep adalah prestasi belajar, minat belajar, sikap terhadap mata pelajaran matematika, dan sebagainya.

Variabel dapat digolongkan menurut penampilan yang diukur. Menurut penggolongan ini, variabel dapat dibedakan menjadi variabel performansi maksimal dan variabel performansi tipikal (Cronbach, 1984). 1) Variabel performansi maksimal (maximum performance) adalah variabel yang dalam pengumpulan datanya responden didorong untuk menunjukkan penampilan maksimalnya. Berdasarkan penampilan maksimalnya, dapat diketahui kemampuan responden dalam variabel yang diukur. Termasuk dalam variabel performansi maksimal adalah prestasi belajar, kreativitas, kemampuan verbal, kemampuan numerik, kecerdasan, kemampuan penyesuaian diri, potensi akademik, bakat musik dan sebagainya. Alat ukur 
pengumpulan data variabel performansi maksimal adalah tes, sehingga dikenal tes prestasi belajar, tes kreativitas, tes kemampuan verbal, tes kecerdasan, tes potensi akademik, tes bakat dan sebagainya. 2) Variabel performansi tipikal adalah variabel yang dalam pengumpulan datanya responden tidak didorong untuk menunjukkan penampilan maksimalnya, tetapi lebih didorong untuk melaporkan secara jujur keadaan dirinya apa adanya sehubungan dengan variabel yang diukur. Misalnya : dalam pengumpulan data "motivasi belajar" di mana responden diminta memberikan respons atas butir-butir instrumen dengan lima pilihan (tidak pernah, jarang, kadang, sering, selalu). Responden tidak didorong untuk memberikan respons setinggi mungkin dengan sesering mungkin menjawab "selalu", tetapi didorong untuk memberikan jujur sesuai keadaan yang dialami dan dirasakan. Termasuk dalam variabel performansi tipikal adalah usia, jenis kelamin, agama, pendidikan, minat belajar, penilaian terhadap kemampuan guru, sikap terhadap mata pelajaran IPA, konsep diri, percaya diri, tipe kepribadian dan sebagainya. Alat ukur pengumpulan data untuk variabel performansi tipikal adalah instrumen nontes.

\section{PENGUMPULAN DATA DALAM PENELITIAN SOSIAL DAN PENDIDIKAN}

Pengumpulan data dalam penelitian sosial dan pendidikan diawali dari populasi atau sampel. Populasi adalah keseluruhan objek dalam pendidikan yang mempunyai satu karakteristik yang sama. Kesamaan dalam satu karakteristik membawa objek-objek masuk ke dalam satu populasi yang sama. Data dikumpulkan dari populasi atau sampel. Populasi atau sampel merupakan objek yang darinya akan dilakukan pengukuran untuk pengumpulan data. Objek dalam penelitian sosial dan pendidikan dari mana data akan diambil dikenal dengan responden. Pengumpulan data dilakukan dengan mengukur respons yang diberikan oleh responden. Populasi (diwakili sampel) terdiri dari responden dengan satu persamaan karakteristik. Di samping para responden dalam populasi (diwakili sampel) mempunyai persamaan, di antara mereka mengandung sejumlah 
perbedaan. Perbedaan responden dalam satu populasi merupakan variabel. Data yang diambil data tentang variabel dari responden yang diukur variabelnya. Hal itu dapat digambarkan sebagai berikut :

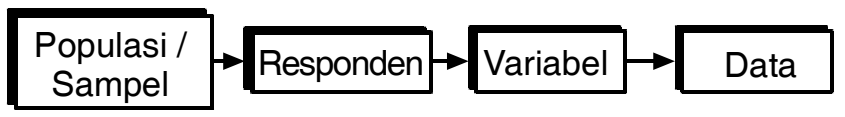

\section{Sumber pengumpulan data}

Responden diambil dari sumber pengumpulan data. Sumber pengumpulan data dapat berupa populasi atau sampel. Bila keseluruhan objek yang memiliki kesamaan karakteritik itu diteliti dan dikumpulkan datanya, maka sumber pengumpulan data adalah populasi. Dalam keadaan demikian, seluruh anggota populasi menjadi responden. Namun bila sebagian saja dari keseluruhan objek yang diteliti dan dikumpulkan datanya maka sumber pengumpulan data adalah sampel. Oleh karena itu responden hanya berasal dari sampel. Sampel adalah sebagian dari populasi yang ditentukan dengan teknik tertentu sehingga mempunyai sifat yang sama dengan populasi. Penelitian dan pengumpulan data dari sebagian populasi dimaksudkan agar penelitian menangani lebih sedikit objek dengan tetap mempertahankan kualitas penelitian walaupun hanya dilakukan atas sampel, karena lebih dari sebagian populasi, sampel juga mempunyai ciri yang sama dengan populasi karena diambil dengan teknik tertentu yang dapat dipertanggungjawabkan.

\section{Responden penelitian}

Dalam penelitian pendidikan, objek yang menjadi responden dapat berupa manusia pelaku pendidikan dan hasil karya manusia pelaku pendidikan. 1) Objek penelitian pendidikan berupa manusia pelaku pendidikan terdiri dari manusia yang terlibat dalam aktivitas pendidikan. Mereka dapat berupa siswa (mahasiswa, peserta belajar, peserta pelatihan, dan sebagainya), guru (dosen, tutor, instruktur, widyaiswara, pamong, dan sebagainya), karyawan, kepala sekolah (rektor, ketua, direktur, pimpinan, dan 
sebagainya), orang tua / wali, komite sekolah, kantor departemen pendidikan, pengawas, dan sebagainya. 2) Objek penelitian pendidikan juga dapat berupa hasil karya manusia pelaku pendidikan. Mereka dapat berupa kurikulum (dibuat oleh pengembang kurikulum), media pengajaran (dibuat oleh guru atau pengembang media), metode mengajar (dikembangkan oleh guru atau ahli instruksional), tugas rumah (dibuat oleh siswa), karya sastra (tugas dibuat oleh siswa), buku teks (dibuat oleh penulis buku), tes hasil belajar (dibuat oleh guru atau pengembang tes hasil belajar lain), dan sebagainya.

\section{Variabel}

Data dalam penelitian pendidikan dikumpulkan dari variabel yang dimiliki oleh responden. Responden penelitian pendidikan menjadi sumber pengumpulan data karena mempunyai satu kesamaan karakteristik karena berasal dari populasi atau sampel yang mempunyai sifat sama dengan populasi. Meskipun responden mempunyai satu kesamaan karakteristik, mereka mempunyai perbedaan dalam hal lainnya. Perbedaan itu merupakan variabel. Menurut Ghiselli, Campbell dan Zedeck (1981 : 10), variabel merupakan karakteristik atau kualitas yang individu berbeda satu sama lain. Misalnya : prestasi belajar siswa SLTP se-Surakarta. Populasi adalah seluruh siswa SLTP se-Surakarta. Pengumpulan data dapat dilakukan atas populasi atau sampel. Bila pengumpulan data akan dilakukan atas seluruh siswa SLTP seSurakarta maka sumber pengumpulan data adalah populasi. Sedang bila pengumpulan data hanya akan dilakukan atas sebagian dari siswa SLTP se-Surakarta, maka sumber pengumpulan data adalah sampel. Populasi atau sampel siswa SLTP se-Surakarta merupakan reponden yang mempunyai kesamaan karakteritik yaitu siswa SLTP se-Surakarta. Populasi atau sampel akan menjadi responden yang darinya data akan dikumpulkan. Meski sama-sama siswa SLTP se-Surakarta, di antara mereka terdapat perbedaan dalam hal yang lain, salah satunya adalah prestasi belajar. Prestasi belajar merupakan variabel (yang membedakan seorang siswa dari yang lain). Bila 
sumber pengumpulan datanya adalah populasi, maka data prestasi belajar diukur (dikumpulkan) dari seluruh siswa SLTP se-Surakarta dengan melakukan testing.

Variabel-variabel penelitian pendidikan dapat diidentifikasi dari objek-objek penelitian pendidikan yang menjadi anggota populasi tertentu. Objek dapat dikelompokkan menjadi dua yaitu manusia pelaku pendidikan dan hasil karya manusia pelaku pendidikan. Manusia pelaku pendidikan dapat berupa siswa, guru, kepala sekolah, karyawan, orang tua / wali, komite sekolah, pengurus yayasan, kantor departemen pendidikan, dan sebagainya. Hasil karya manusia pelaku pendidikan dapat berupa tugas siswa, tes hasil belajar, kurkulum, buku teks, media pembelajaran, metode mengajar, dan sebagainya.

Dari objek penelitian pendidikan berupa manusia pelaku pendidikan dapat diidentifikasi variabel. 1) Dari objek berupa siswa, variabel dapat berupa usia, agama, jenis kelamin, suku bangsa, berat badan, tinggi badan, minat belajar, sikap terhadap mata pelajaran IPA, kecerdasan, bakat olah raga, prestasi belajar, pekerjaan orang tua, tempat tinggal, motivasi belajar, kreativitas, status sosial ekonomi, penilaian terhadap kinerja guru, jumlah saudara kandung, urutan kelahiran, minat menjadi guru, konsep diri, harga diri, toleransi, kepekaan sosial, kejujuran, religiusitas, agresivitas, modernitas, pandangan terhadap sekolah, perilaku kejenisan (sex role), kecemasan, pola asuh orang tua, kemampuan numerik, kemampuan verbal, penyesuaian diri, penguasaan bahasa asing, motivasi berprestasi, kemandirian belajar, tipe kepribadian, kepuasan terhadap layanan sekolah, prasangka terhadap kelompok agama lain, perhatian orang tua, perhatian guru, aspirasi berprestasi, kecerdasan emosi, kecerdasan spiritual, kemampuan berpikir kritis, kemampuan awal, kesiapan belajar, kecepatan belajar, kondisi fisik, sikap terhadap tugas belajar, kedisiplinan belajar, kedisiplinan di sekolah, dan sebagainya. 2) Dari objek penelitian berupa guru, 
sejumlah variabel yang dapat diidentifikasi yaitu jenis kelamin, agama, suku, usia, lama mengajar, penghasilan, jumlah anak, pendidikan, kemampuan mengajar, motivasi berprestasi, penguasaan materi, pola mengajar, status sosial ekonomi, perhatian terhadap siswa, kualitas mengajar, kewibawaan, keteladanan, kemampuan bekerja sama, gaya mengajar, kedisiplinan mengajar, tanggung jawab profesi, dan sebagainya. 3) Dari objek penelitian berupa kepala sekolah, sejumlah variabel dapat diidentifikasi seperti : jenis kelamin, usia, penghasilan, pendidikan, pengalaman memimpin, lama bekerja, status perkawinan, jumlah anak, produktivitas kerja, pola kepemimpinan, gaya kepemimpinan, agama, suku, status sosial ekonomi, motivasi kerja, motivasi berprestasi, perhatian terhadap sekolah, kualitas kepemimpinan, kewibawaan, kecerdasan intelektual, kecerdasan emosi, kecerdasan spiritual, keteladanan, kedisiplinan kerja dan sebagainya. 4) Dari objek penelitian berupa orang tua sejumlah variabel dapat diidentifikasi seperti : usia, agama, suku, harapan terhadap sekolah, pekerjaan, pola pengasuhan, status sosial ekonomi, penghasilan, jumlah anak, motivasi menyekolah anak, pendidikan, perhatian terhadap anak, kualitas pengasuhan anak, kewibawaan, keteladanan, dan sebagainya. 5) Dari objek berupa orang yang penting bagi anak (significant others) dapat diidentifikasi sejumlah variabel seperti : usia, jenis kelamin, agama, hubungan dengan anak, pekerjaan, suku, perhatian terhadap anak, dan sebagainya. 6) Dari objek berupa pemerintah daerah dapat diidentifikasi sejumlah variabel seperti : alokasi APBD terhadap pendidikan, perhatian terhadap guru, perhatian terhadap sekolah, motivasi memajukan pendidikan, dan sebagainya. 7) Dari objek berupa petugas bimbingan penyuluhan dapat diidentifikasi sejumlah variabel seperti : pendidikan, usia, agama, jenis kelamin, perhatian terhadap siswa, kecerdasan, dan sebagainya. 8) Dari objek berupa pengguna lulusan dapat diidentifikasi sejumlah variabel seperti bidang usaha, harapan terhadap pegawai, besarnya penawaran gaji, cara merekrut pegawai, pandangan terhadap 
lulusan, dan sebagainya. 9) Dari objek berupa komite sekolah atau wali amanat dapat diidentifikasi sejumlah variabel seperti : pemahaman terhadap tugas dan fungsi, pendidikan, pekerjaan, efektivitas kerja dan sebagainya. 10) Dari pengelola ekstrakurikuler dapat diidentifikasi sejumlah variabel seperti : jenis kelamin, status perkawinan, besar gaji, jumlah anak, pendidikan, motivasi membina ekstrakurikuler, jenis ekstrakurikuler, dan sebagainya. 11) Dari objek berupa penilik sekolah variabel dapat berupa : usia, jenis kelamin, pendidikan, metode supervisi, frekuensi supervisi, dan sebagainya. 12) Dari objek berupa teman sekolah dapat diidentifikasi variabel seperti : jenis kelamin, usia, kedekatan hubungan dengan anak, tipe kepribadian, penyesuaian diri, dan sebagainya.

Dari objek penelitian pendidikan berupa hasil karya manusia pelaku pendidikan sejumlah variabel dapat diidentifikasi. 1) Dari objek berupa kurikulum dapat diidentifikasi sejumlah variabel seperti : penyerapan muatan lokal, kesesuaian dengan taraf perkembangan siswa, relevansinya dengan pembentukan kompetensi, kejelasan tujuan, dan sebagainya. 2) Dari objek berupa buku teks dapat diidentifikasi sejumlah variabel : kualitas bahan, jumlah halaman, keterbacaan, kelengkapan isi, kesesuaian dengan kurikulum, harga, bias jender, keluasan materi, kesesuaian dengan kebudayaan anak, kejelasan bahasa, rasialisme, dan sebagainya. 3) Dari objek berupa sistem evaluasi dapat diidentifikasi sejumlah variabel seperti : bentuk tes, jenis tes, waktu pengerjaan, cara pengujian, kualitas tes, skala, acuan penilaian, dan sebagainya. 4) Dari objek berupa sekolah atau lembaga pendidikan dapat diidentifikasi sejumlah variabel : kelayakan gedung, jumlah bangunan, kedisiplinan, hubungan dengan pemasok, hubungan dengan pengguna, kenyamanan, efektivitas kerja, efisiensi kerja, produktivitas kerja, transparansi, dan sebagainya. 5) Dari objek berupa ruang kelas dapat diidentifikasi sejumlah variabel seperti : kenyamanan, pencahayaan, pertukaran udara, penataan, dan sebagainya. 6) 
Dari objek berupa media pembelajaran dapat diidentifikasi sejumlah variabel seperti : bahan, jenis, harga, kualitas, kejelasan, kemampuan menarik perhatian, dan sebagainya. 7) Dari objek berupa lingkungan dapat diidentifikasi sejumlah variabel seperti : kondisi ekonomi, keadaan sosiopolitik, pandangan terhadap pendidikan, kebijakan makro pemerintah di bidang pendidikan, dan sebagainya. 8) Dari objek berupa metode pembelajaran dapat diidentifikasi sejumlah variabel seperti : jenis, kesesuaian dengan topik pembelajaran, keterlibatan siswa dalam pembelajaran, demokratisme, dan sebagainya. 9) dari objek berupa fasilitas dapat diidentifikasi sejumlah variabel seperti : bahan, jenis, kesesuaian dengan kebutuhan, dan sebagainya. 10) Dari objek berupa tugas mengarang yang dibuat oleh siswa dapat diidentifikasi sejumlah variabel seperti : jumlah kata, alur pembahasan, kekuatan argumentasi, kejelasan pembahasan, dan sebagainya.

Apabila ditinjau dari kedudukan variabelnya, tidak ada variabel terikat dalam penelitian sosial dan pendidikan yang disebabkan oleh satu variabel bebas. Setiap akibat dalam gejala sosial dan pendidikan selalu disebabkan oleh penyebab yang tidak tunggal. Walaupun begitu, hubungan satu variabel bebas terhadap satu variabel terikat dapat dilihat dengan mengontrol masuknya variabel bebas yang lain. Semakin banyak variabel bebas yang mempunyai kemungkinan mempengaruhi variabel terikat masuk ke dalam model, maka semakin baik peramalan yang dibuat. Penambahan variabel bebas akan meningkatkan kecermatan prediksi atas variabel terikat (Marascuilo dan Levin, 1983 : 76).

Variabel dalam penelitian sosial dan pendidikan dapat digolongkan menurut sifatnya, sehingga dalam penelitian sosial dan pendidikan terdapat variabel yang bersifat kategori, diskrit dan kontinum. Beberapa variabel yang merupakan variabel kategori adalah suku bangsa, jenis kelamin, agama, asal tempat tinggal, asal sekolah, pendidikan, dan sebagainya. Termasuk variabel 
yang bersifat diskrit adalah jumlah saudara, jumlah anak, besar pendapatan, jumlah siswa, jumlah guru, jumlah sekolah, jumlah sekolah swasta dan sebagainya. Sedang termasuk variabel yang mempunyai sifat kontinum adalah tipe kepemimpinan, kualitas mengajar, penguasaan materi, prestasi belajar, kecerdasan emosi, dan sebagainya. Dalam penelitian pendidikan, variabel kontinum kadang-kadang diubah menjadi variabel kategori dengan cara menyusun klasifikasi menurut ketentuan tertentu. Kadangkadang variabel kontinum dijadikan dikotomo atau trikotomi secara artifisial (Kerlinger, 1996 : 281). Misalnya : motivasi belajar sebenarnya merupakan variabel kontinum. Untuk kepentingan pengelompokkan reponden dan membedakannya di antara kelompok maka variabel motivasi belajar dapat diubah menjadi variabel kontinum dengan klasifikasi sebagai berikut :

\begin{tabular}{|c|c|}
\hline Kelas & Kategori \\
\hline $21-40$ & Rendah \\
\hline $41-60$ & Sedang \\
\hline $61-80$ & Tinggi \\
\hline
\end{tabular}

Dari klasifikasi tersebut diketahui bahwa variabel motivasi belajar diubah dari variabel kontinum menjadi variabel kategori di mana responden yang mempunyai skor motivasi belajar antara 21 sampai 40 tergolong kelompok responden yang mempunyai motivasi belajar rendah, responden yang mempunyai skor motivasi belajar antara 41 sampai 60 tergolong kelompok responden yang mempunyai motivasi belajar sedang, dan responden yang mempunyai skor motivasi belajar antara 61 sampai 80 tergolong kelompok responden yang mempunyai motivasi belajar tinggi.

Menurut skalanya, sebagian besar variabel dalam penelitian sosial dan pendidikan mempunyai skala nominal dan ordinal. Termasuk variabel penelitian sosial dan pendidikan yang mempunyai skala nominal adalah jenis kelamin, agama, suku 
bangsa, pekerjaan, pendidikan, pengalaman mengajar, jumlah saudara, golongan darah, usia, dan sebagainya. Termasuk variabel dalam penelitian sosial dan pendidikan yang mempunyai data dengan skala ordinal adalah minat belajar, kemampuan mengajar, kecerdasan, prestasi belajar dan sebagainya. Tidak ada variabel dalam penelitian pendidikan yang secara nyata memiliki skala hingga tingkat interval, apalagi rasio. Penggunaan rumus statitstika parametrik - yang memungkinkan kesimpulannya digeneralisir - mempersyaratkan skala datanya paling tidak interval. Untuk tidak menutup kesempatan penelitian sosial dan pendidikan menggunakan statistika parametrik dan karenanya kesimpulan hasil penelitian dapat digeneralisir, maka dalam penelitian pendidikan data variabel dikumpulkan dengan membuat penskalaan sehingga data hasil pengukurannya yang sebenarnya ordinal dapat diasumsikan memiliki skala pada tingkat interval dan analisis datanya dapat menggunakan statistika parametrika. Penskalaan (scaling) adalah prosedur penempatan atribut atau karakteristik objek pada titik-titik tertentu sepanjang kontinum (Azwar, 2001 : 97). Menurut Kerlinger (1996: 706), kebanyakan skala yang digunakan dalam ilmu sosial adalah ordinal, namun dapat diasumsikan interval yang punya interval yang sama karena : 1) ukuran-ukuran yang berelasi secara substansial dan linear dapat diasumsikan adanya interval yang sama. Semakin relasi mendekati linearitas, semakin mendekati sama interval-interval pada skala tersebut. Dengan begitu, skala ordinal sama dengan skala interval, 2) metode penskalaan dan transformasi untuk mengubah skala ordinal menjadi skala interval. Beberapa cara penskalaan dapat dilakukan : skala Likert, skala pilihan ganda dari Inkels, skala Thurstone dengan skala 1-11, skala Guttman dengan pilihan ya dan tidak, serta semantik diferensial dengan akala $1-7$. 


\section{E. PENUTUP}

Dalam pengumpulan data terdapat dua hal yang harus dipertimbangkan : 1) Objek apa yang akan diukur. Pertanyaan ini berhubungan dengan objek yang mempunyai sifat yang akan diukur. Pengukuran dilakukan atas sifat dari objek-objek (populasi atau sampelnya). 2) Sifat apa yang akan diukur. Objek-objek mempunyai kesamaan dalam satu karakteristik sehingga menjadi satu populasi. Untuk memperoleh penyederhanaan dalam pengumpulan data mungkin pengumpulan tidak dilakukan atas populasi tetapi atas sampel. Di samping objek-objek mempunyai kesamaan dalam satu karakteristik, antara objek-objek mempunyai perbedaan dalam karakteristik yang lain yang disebut variabel. Data variabel dikumpulkan dengan mengukur kepemilikan variabel pada objek-objek.

Dalam pengumpulan data dalam penelitian pendidikan juga terdapat dua hal yang harus dipertimbangkan : 1) Dari siapa pengumpulan data akan dilakukan. Pertanyaan ini berhubungan dengan objek yang mempunyai sifat yang akan diukur yang dikenal sebagai reponden. Pengukuran dilakukan atas karakteristik dari responden (populasi atau sampelnya). 2) Karakteristik apa yang akan diukur. Responden mempunyai kesamaan dalam satu karakteristik sehingga menjadi satu populasi. Untuk memperoleh penyederhanaan dalam pengumpulan data mungkin pengumpulan tidak dilakukan atas populasi tetapi atas sampel. Di samping responden mempunyai kesamaan dalam satu karakteristik, antara responden mempunyai perbedaan dalam karakteristik yang lain yang disebut variabel. Data variabel dikumpulkan dengan mengukur kepemilikan variabel pada responden. 


\section{DAFTAR PUSTAKA}

Bouma, Gary D (1993). The research proccess. Oxford: Oxford University Press

Cronbach, Lee J (1984). Essentials of psychological testing. $4^{\text {th }}$ edition. New York : Harper and Row

Ghiselli, Edwin E; Campbell, John P dan Zedeck, Sheldon (1981).

Measurement theory for the behavioral sciences. San Fransisco

: WH Freeman and Company

Kerlinger, Fred N (1996). Asas-asas penelitian behavioral. Terjemahan

Landung R Simatupang. Yogyakarta : Gadjah Mada University Press Marascuilo, Leonard A dan Levin, Joel R (1983). Multivariate statistics in the social sciences : A researcher's guide. Monterey, California : Brooks/Cole Publishing Company

Siegel, Sidney (1997). Statistika Nonparametrik. Terjemahan Zanzawi

Suyuti dan Landung R Simatupang. Jakarta : PT Gramedia. 